\title{
ASSESSMENT KLASTER PERIKANAN (STUDI PENGEMBANGAN KLASTER RUMPUT LAUT KABUPATEN SUMENEP)
}

\author{
Oleh \\ Armen Zulham, Agus Heri Purnomo, Tenny Apriliani \\ dan Yayan Hikmayani*
}

\begin{abstract}
ABSTRAK
Klaster adalah strategi pengembangan wilayah untuk memanfaatkan potensi ekonomi. Wacana klaster perikanan tidak lepas dari strategi tersebut, tujuannya untuk mendorong pengembangan sentra industri perikanan. Penelitian dilakukan bulan Mei 2007 pada lokasi pengembangan rumput laut di Kabupaten Sumenep yang merupakan contoh daerah sasaran pengembangan klaster rumput laut. Tujuan dari kajian ini adalah: i) mengidentifikasi dan mempelajari berbagai karakteristik konsep klaster dalam hubungannya dengan pengembangan industri perikanan; ii) mempelajari karakteristik dan hubungan unit usaha pada sentra perikanan terkait dengan pengembngan klaster perikanan dan iii) merumuskan strategi pengembangan klaster rumput laut di Sumenep. Penelitian dilakukan dengan survey melalui wawancara dengan responden. Responden yang diwawancara meliputi: pejabat pemerintah, pembudidaya rumput laut, pedagang, pengolah dan eksportir rumput laut, pengusaha jasa transportasi dan tokoh masyarakat setempat. Hasil kajian ini menunjukkan di Sumenep telah ada komponen-komponen pembentuk klaster rumput laut. Penelitian ini juga menunjukkan tejadi konflik horizontal pada usaha perdagangan dan industri pegolahan produk primer menjadi intermediate product. Pada sisi lain hubungan vertikal antar komponen usaha industri rumput laut cenderung mendorong terjadi asimetris informasi terutama antara pembudidaya rumput laut dengan pedagang. Pengkajian ini merekomendasikan kluster rumput laut di Sumenep harus dibangun berdasarkan prinsip: consumer oriented, klaster harus bersifat kolektif, dan kumulatif.
\end{abstract}

\section{Kata Kunci : Klaster, Rumput Laut, Hubungan Bisnis, Sumenep}

\section{Abstract : Assesment of Fisheries Cluster (Development Case of Seaweed Cluster in Sumenep District). By Armen Zulham, Agus Heri Purnomo, Tenny Apriliani and Yayan Hikmayani}

Cluster is a strategy for regional development to support local economic potency. The opinion of fisheries cluster will be developed closed to that strategy, with aiming to establish fisheries industrial complex. Research was conducted in Sumenep (Madura) on May 2007as the target area for the establishment of the fisheries cluster complex. The purposes of this research were: i) to identify and study the fisheries industrial cluster complex characteristics related to the development of fisheries industry, ii) to study the characteristic and pattern linkages among industrial units in fisheries center related to institutional development, and iii) to generate suggested recommendation for seaweed cluster industrial complex in Sumenep district. Data were collected through survey in the respected area; the respondents covered the local government officers, seaweed farmers, seaweed processors, local traders, exporters, local transportation services and local leaders. The research findings were: there were many seaweed industry units in Sumenep which can be used as the main component to organize the establishment of the seaweed industrial cluster complex, in order to get horizontal conflict among traders and seaweed processors were existed the seaweed from the farmers. On the other hand, the vertical relationship among industrial units tend to make asymmetric information on price and product criteria between traders and seaweed farmers. This research recommends the seaweed cluster industrial complex in Sumenep can be developed on the basis of: consumer oriented, collective and cumulative approach.

Key Words : Cluster, Seaweed, Business Relationship, Sumenep.

\footnotetext{
* Peneliti Pada Balai Besar Riset Sosial Ekonomi Kelautan dan Perikanan, BRKP-DKP. JI. KS TUBUN Petamburan VI Slipi Jakarta 10260. Telp. (021) 53650162
} 


\section{PENDAHULUAN}

Konsep klaster dipopulerkan oleh Porter (1990) dalam tulisan the Competitive Advantages of Nations, melalui model yang disebut "diamond of advantage". Model ini menggambarkan daya saing satu wilayah ditentukan oleh kerja sama yang serasi antar unit usaha dan industri yang terdapat di wilayah tersebut. Perhatian mendalam tentang pengembangan klaster dimulai sejak tahun 1980-an dan 1990-an setelah keberhasilan klaster industri di Italia dan beberapa negara Eropa (Humprey \& Schmitz, 1995).

Wacana tentang klaster perikanan sangat beragam, namun mengacu pada konsep diatas, unit-unit usaha dan kelembagaan dalam klaster perikanan diharapkan memerankan fungsi/hubungan yang saling mendukung untuk pengembangan ekonomi pada daerah tersebut. Dengan demikian pada wilayah pengembangan klaster perikanan tersebut, investasi yang ada dapat berfungsi secara efisien, tepat guna dan mampu mendorong pertumbuhan ekonomi lokal maupun nasional secara maksimal.

Berkaitan dengan uraian diatas, maka perlu dilakukan pengkajian awal tentang klaster perikanan, agar dapat dijadikan landasan bagi pengambil kebijakan untuk mempertimbangkan bentuk klaster perikanan yang sedang diwacanakan saat ini. Kajian tersebut diharapkan, paling tidak dapat memberi gambaran mendasar tentang besar peluang keberhasilan implementasi konsep klaster pada sektor perikanan, sehingga dapat ditentukan strategi untuk menerapkan konsep klaster di sektor perikanan (apakah supply driven based strategy ${ }^{1}$ atau demand driven based strategy ${ }^{2}$ ). Kedua strategi ini mempunyai karakteristik yang berbeda sehingga membawa implikasi keberhasilan yang tidak sama.

Oleh sebab itu tujuan dari kajian ini adalah untuk (1) mengidentifikasi dan mempelajari: berbagai karakteristik usaha rumput laut di Kabupaten Sumenep terkait dengan pengembangan klaster; (2) mempelajari fungsi, dan bentuk hubungan komunitas usaha di berbagai sentra perikanan dalam hubungannya dengan kelembagaan klaster rumput laut, serta (3) menentukan strategi pengembangan klaster rumput laut di Sumenep.

\section{METODE}

\section{Lokasi dan Waktu Penelitian}

Penelitian ini dilakukan pada lokasi pengembangan rumput laut di Kabupaten Sumenep. Lokasi contoh tersebut, merupakan wilayah sasaran pengembangan klaster rumput laut dan pada lokasi tersebut terdapat embrio unit usaha pembentuk klaster. Terkait dengan rencana pengembangan klaster rumput laut tersebut, maka dilakukan survey cepat pada bulan Mei 2007 di Kabupaten Sumenep untuk menggali informasi tentang potensi pengembangan industri rumput laut. Penelitian survei merupakan perangkat penelitian yang murah dan cepat sehingga informasi yang dibutuhkan dapat dihasilkan secara akurat dan tepat waktu. Bentuk kuesionernya pun sederhana dan relatif mudah sehingga tidak memerlukan pelatihan secara khusus (Stone, 1993), teknik survei ini dikenal sebagai metode survei cepat (Rapid Survey Method). Lokasi usaha rumput laut yang dikunjungi adalah meliputi: a). Kecamatan Talango, desa Padike. b). Kecamatan Bluto, desa Pagar Batu; desa Pekandangan; dan desa Aeng Dake.

\section{Jenis dan Sumber Data}

Data yang dikumpulkan merupakan data sekunder dan data primer. Data sekunder

\footnotetext{
${ }^{1}$ Berdasar pada kelimpahan sumberdaya (resource abundante) dan didukung oleh potensi pasar

${ }^{2}$ Berdasar pada pasar dan didukung oleh kelimpahan sumberdaya (resource abundance)
} 
yang dikumpulkan meliputi data potensi dari komoditas yang diteliti, harga dan kebijakan daerah terhadap pengembangan komoditas tersebut. Sementara itu, data primer yang dikumpulkan dilakukan dengan panduan kuisioner meliputi karakteristik unit usaha yang terlibat dalam industri rumput laut, biaya produksi dan penjualan komoditas tersebut, jaringan pemasaran serta kendala-kendala dalam pengembangan komoditas rumput laut.

Responden yang diwawancara dikelompokkan menjadi: 1) pejabat pemerintah yang terkait dengan pengembangan komoditas (Dinas Perikanan dan Kelautan Propinsi Jawa Timur dan Kabupaten Sumenep), 2) pembudidaya rumput laut, 3) pedagang, 4) pengolah dan eksportir komoditas rumput laut, 5) pengusaha penyedia jasa distribusi barang dan 6) tokoh masyarakat pada daerah tersebut.

\section{Analisis Data}

Secara umum pendekatan penelitian ini adalah pendekatan eksploratif yang menjelaskan fenomena lapangan. Data yang diperoleh ditampilkan dalam bentuk tabeltabel analisis. Data tersebut dianalisis secara deskriptif untuk menjelaskan berbagai karakterstik, perilaku dan fenomena yang terkait dengan perkembangan komponenkomponen industri rumput laut.

\section{HASIL DAN PEMBAHASAN}

\section{Bentuk Klaster di Pedesaan}

Peran klaster dalam pembangunan di Indonesia telah diteliti oleh Abdullah (2002), Direktorat Kawasan Khusus dan Tertinggal Bapenas (2003), dan Kuncoro et al (2003), serta JICA (2003). Kajian tersebut menunjukkan klaster di Indonesia terdiri dari unit-unit usaha kecil dan menengah (UKM) yang terkonsentrasi pada kawasan tertentu di pedesaan. Berdasarkan konsentrasi tersebut maka bentuk-bentuk klaster di Indonesia dapat di katagorikan sebagai: pertama, klaster industri yang terbentuk secara alamiah tanpa intervensi pemerintah. Dan kedua, klaster industri yang berkembang karena intervensi pemerintah.

Klaster menurut kategori pertama terbentuk oleh kegiatan ekonomi masyarakat secara turun temurun. Ciri ekonomi dari klaster ini adalah skala ekonominya kecil, jumlah pekerja per unit usaha antara 5 - 10 orang dan diupah harian, inovasi produk sangat jarang terjadi. Klaster yang demikian umumnya merupakan UKM dengan jenis produk homogen dan segmen pasar yang seragam. Keseragaman produk maupun pasar mendorong unit usaha didalam klaster ini membentuk kerja sama horizontal (Integrated horizontally cluster), untuk menjamin pasokan produk dan menjaga kepercayaan pasar.

Sementara klaster menurut katagori kedua, didorong oleh upaya pengembangan potensi ekonomi dalam rangka melaksanakan program pemerintah. Klaster ini dibentuk untuk memanfaatkan peluang pasar, memperbaiki kualitas produk dan membuka lapangan kerja. Unit usaha pembentuk klaster ini umumnya memanfaatkan kemudahan atau fasilitas yang disediakan pemerintah, inovasi baru sangat cepat diadopsi, kompetisi pasar produk antar unit usaha sangat ketat, jumlah pekerja per unit usaha lebih dari 20 orang dan terdapat beberapa pekerja yang bergaji tetap. Oleh sebab itu untuk menjamin investasi dan mengatasi persaingan yang tidak sehat pemerintah membuat aturan terhadap unit usaha yang ada didalam klaster.

\section{Karakteristik Unit Usaha di Lokasi Penelitian}

Kegiatan usaha yang terdapat pada lokasi penelitian meliputi usaha pendukung proses produksi, usaha produksi, usaha jasa distribusi barang dan usaha jasa pelayanan lainnya. Masing-masing jenis usaha terdiri dari beberapa unit usaha yang mendukung dengan karakteristik yang berbeda-beda. Karakteristik pada setiap unit usaha dapat dilihat pada Tabel 1. 
Tabel 1. Karakteristik Unit Usaha Rumput Laut di Kabupaten Sumenep, Tahun 2007

Table 1. Characteristic of Seaweed Business Unit in Sumenep Sub Province, 2007

\begin{tabular}{|c|c|c|c|}
\hline $\begin{array}{l}\text { No } \\
\text { No }\end{array}$ & $\begin{array}{c}\text { Jenis Usaha } \\
\text { Type of Business }\end{array}$ & $\begin{array}{l}\text { Unit Usaha } \\
\text { Business Unit }\end{array}$ & $\begin{array}{c}\text { Karakteristik Unit Usaha } \\
\text { Characteristic of Business Unit }\end{array}$ \\
\hline \multirow[t]{2}{*}{$\mathrm{A}$} & $\begin{array}{l}\text { Usaha Pendukung } \\
\text { Proses Produksi } \\
\text { Rumput } \\
\text { Laut/Supported } \\
\text { Business of } \\
\text { Seaweed } \\
\text { Production Process }\end{array}$ & $\begin{array}{l}\text { 1. Unit usaha } \\
\text { pembibitan } \\
\text { rumput laut/ } \\
\text { Business Unit of } \\
\text { Seaweed Seed }\end{array}$ & $\begin{array}{l}\text { - Belum berkembang secara komersial/Not } \\
\text { commercial developed } \\
\text { - Pembelian bibit rumput laut antar } \\
\text { pembudidaya/ Seaweed seed purchaising } \\
\text { between fish farmer } \\
\text { - Belum ada pengelolaan usaha mendapatkan } \\
\text { bibit unggul/No management to get good } \\
\text { seed } \\
\text { - Kebutuhan bibit per tahun sekitar } 53 \text { ton } \\
\text { basah/ Seed needed per year about } 53 \text { ton } \\
\text { wet }\end{array}$ \\
\hline & & $\begin{array}{l}\text { 2. Unit usaha } \\
\text { penyedia sarana } \\
\text { produksi/Busine } \\
\text { ss unit of } \\
\text { production } \\
\text { equipment } \\
\text { producer }\end{array}$ & $\begin{array}{l}\text { - Kebutuhan sarana produksi utama : Bambu } \\
\text { dan tali (tali ris)/Main Production equipment } \\
\text { need : bamboo and rope (ris rope) } \\
\text { - Terbatasnya penyedia sarana produksi } \\
\text { rumput laut/ Limitation of seaweed production } \\
\text { equipment producers } \\
\text { - Bambu diperoleh dari desa sekitar, } \\
\text { sedangkan untuk lokasi budidaya yang } \\
\text { berada di pulau, bambu dari Madura/ } \\
\text { Bamboo is from around village, aquaculture in } \\
\text { the island location, bamboo from Madura } \\
\text { - Tali diperoleh dari toko material di ibukota } \\
\text { kecamatan atau Kota Sumenep/rope obtain } \\
\text { from material store in district or Sumenep city }\end{array}$ \\
\hline B. & $\begin{array}{l}\text { Usaha Produksi } \\
\text { Rumput } \\
\text { laut/Seaweed } \\
\text { Production } \\
\text { Business }\end{array}$ & $\begin{array}{l}\text { 1. Unit usaha } \\
\text { penghasil } \\
\text { produk } \\
\text { primer/Business } \\
\text { Unit of Primary } \\
\text { Product } \\
\text { Producer }\end{array}$ & $\begin{array}{l}\text { - usaha rumah tangga/household business } \\
\text { - Peran perempuan sangat dominan dalam } \\
\text { pengambilan keputusan menanam, } \\
\text { memanen, mengolah dan menjual hasil } \\
\text { panen/Women role are dominant for decision } \\
\text { making to plant, harvesting, processing and } \\
\text { selling crops } \\
\text { - Pembudidaya rumput laut tergabung dalam } \\
\text { kelompok/Seaweed aquaculture merged into } \\
\text { group } \\
\text { - Kepemilikan : rata-rata } 4-10 \text { rakit per } \\
\text { RTP/Ownership : average to } 4-10 \text { raft per } \\
\text { household } \\
\text { - Panen : umur rumput laut } 30-40 \\
\text { hari/Harvesting : seaweed age } 30-40 \text { days } \\
\text { - Produk rumput laut : segar, kering tanpa } \\
\text { garam dan kering bergaram/ Seaweed } \\
\text { product: fresh, dried without salt and dried } \\
\text { with salt }\end{array}$ \\
\hline & & $\begin{array}{l}\text { 2. Unit usaha } \\
\text { pengolah } \\
\text { produk primer }\end{array}$ & $\begin{array}{l}\text { - Terdapat } 3 \text { jenis industri : } 1 \text { ) penghasil chip; } \\
\text { 2) penghasil chip dan powder dan 3) } \\
\text { penghasil rumput laut siap saji/3 industry type }\end{array}$ \\
\hline
\end{tabular}


Lanjutan Tabel 1

\begin{tabular}{|c|c|c|c|}
\hline $\begin{array}{l}\text { No } \\
\text { No }\end{array}$ & $\begin{array}{c}\text { Jenis Usaha } \\
\text { Type of Business }\end{array}$ & $\begin{array}{l}\text { Unit Usaha } \\
\text { Business Unit }\end{array}$ & $\begin{array}{c}\text { Karakteristik Unit Usaha } \\
\text { Characteristic of Business Unit }\end{array}$ \\
\hline & & $\begin{array}{l}\text { menjadi bahan } \\
\text { setengah jadi/ } \\
\text { Business unit of } \\
\text { Middle Product } \\
\text { Producers }\end{array}$ & 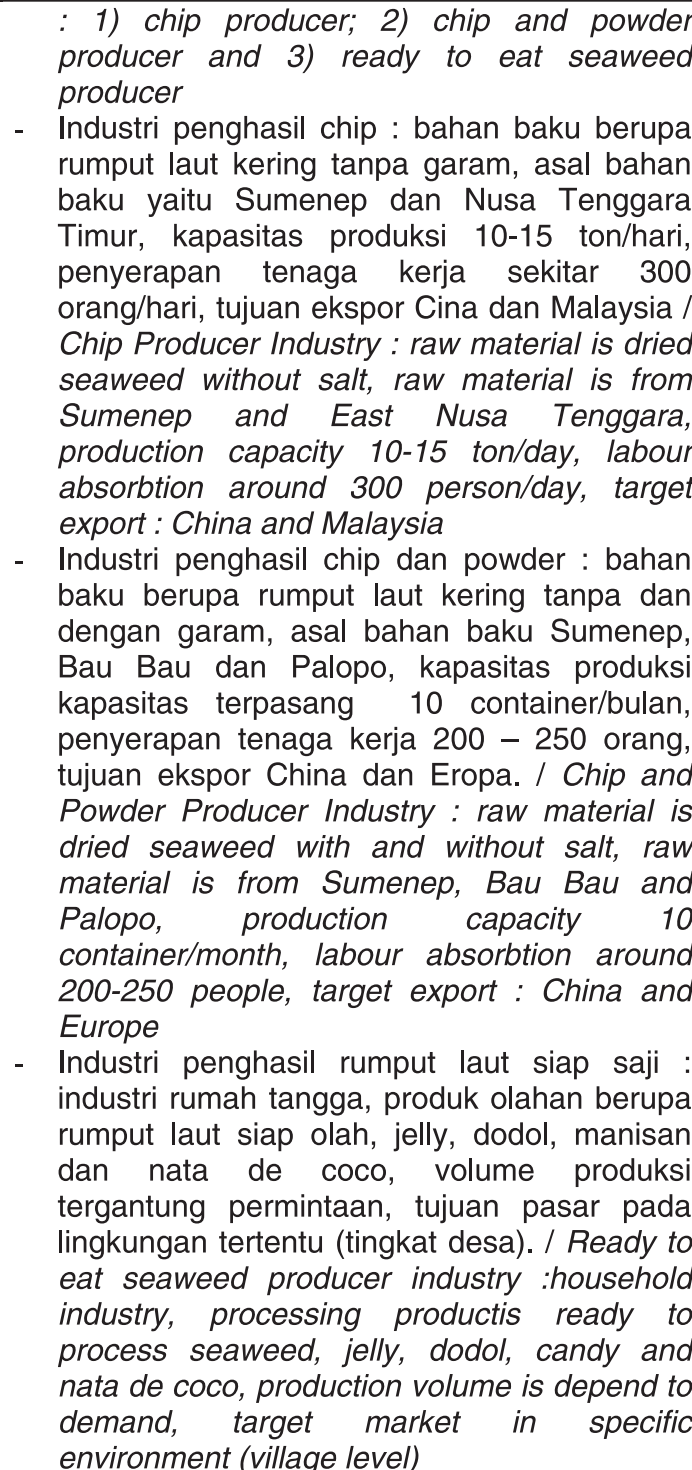 \\
\hline C. & $\begin{array}{l}\text { Usaha Jasa } \\
\text { Distribusi } \\
\text { Barang/Product } \\
\text { Distribution } \\
\text { Services Bussines }\end{array}$ & $\begin{array}{l}\text { 1. Unit usaha } \\
\text { perdagangan } \\
\text { rumput laut/ } \\
\text { Business Unit of } \\
\text { Seaweed } \\
\text { Commerce }\end{array}$ & $\begin{array}{l}\text { Terdiri dari sekitar } 6 \text { pedagang besar dan } \\
\text { lebih dari } 50 \text { pedagang pengumpul./There are } \\
6 \text { wholesaler and more than } 50 \text { collector. } \\
\text { - Peran terbesar adalah pedagang besar, } \\
\text { bertempat di ibukota kecamatan, wilayah } \\
\text { usaha beberapa wilayah kecamatan hingga } \\
\text { daerah lain seperti Sulawesi dan NTT, satu } \\
\text { pedagang besar memiliki } 10-20 \text { pedagang } \\
\text { pengumpul./The biggest role is wholesaler at } \\
\text { the capital of district, business region, some } \\
\text { district region, and other region such as } \\
\text { Sulawesi and NTT, one wholesaler has } 10-20\end{array}$ \\
\hline
\end{tabular}




\begin{tabular}{ccc}
\hline No & Jenis Usaha & Unit Usaha \\
No & Type of Business & Business Unit \\
\hline
\end{tabular}

2. Unit Usaha

Transportasi

Barang/Busines

$s$ Unit of Product

Transportation
1. Unit usaha

Perbankan/Bank ing Business Unit collector.

- Ikatan modal antara pedagang besar dan pengumpul maka pengumpul harus menjual rumput laut kepada pedagang besar./capital tying between wholesaler and collector makes collector must sell seaweed to wholasaler

- Terjadi asimetris informasi. / unsimetrical information happen

- Terdapat 2 perusahaan jasa transportasi barang/There are 2 product transportation sevices company

- Perusahan jasa transportasi barang tergabung dalam satu organisasi transportasi disebut Semut Merah/Those product transportation sevices company is joint into one transportation organization called Red Ant

- Perusahaan baru harus memperoleh izin dengan membayar sejumlah tarif tertentu kepada organisasi./New company must pay amount of tariff to the organization to get permission.

- Terjadi hubungan yang saling ketergantungan antara pedagang besar dan perusahaan jasa transportasi barang./ interdependence relation happend between wholesaler and product transportation sevices company

- Terdapat bank milik pemerintah dan swasta yang berlokasi di pusat kota/There is government and private bank located in downtown.

- Pemanfaat usaha perbankan didominasi pedagang besar./Wholesaler dominate for the banking benefit earning

- Belum ada dana kredit dari perbankan /no credit fundation banking

- Terdapat pemberian kredit melalui program Pemberdayaan Masyarakat Pesisir dari DKP/ There is credit fund from enableness coastal society program of Ministry of Marine and Fisheries Affairs

2. Unit Pelayanan - Instansi pemerintah belum memberikan Publik / Public Services Unit

3. Unit Penelitian dan Pengembangan/ Research and Development Unit pelayanan maksimum terhadap upaya mendorong ekonomi masyarakat setempat./Government institution has not give maximum services to support economy of local society.

- Tahun 1980, percobaan budidaya rumput laut oleh Badan Pengkajian dan Penerapan Teknologi (BPPT) /In 1980, seaweed cultured research by $B P P T$.

- Kualitas pasca panen rumput laut yang bervariasi dibutuhkan peran lembaga 
Lanjutan Tabel 1

\begin{tabular}{|c|c|c|c|}
\hline $\begin{array}{l}\text { No } \\
\text { No }\end{array}$ & $\begin{array}{c}\text { Jenis Usaha } \\
\text { Type of Business }\end{array}$ & $\begin{array}{c}\text { Unit Usaha } \\
\text { Business Unit }\end{array}$ & $\begin{array}{c}\text { Karakteristik Unit Usaha } \\
\text { Characteristic of Business Unit }\end{array}$ \\
\hline & & & $\begin{array}{l}\text { penelitian, penyuluh maupun pedagang besar } \\
\text { untuk meningkatkan kualitas./Variation the } \\
\text { quality of seaweed post harvest need role of } \\
\text { research institution, extention agent or } \\
\text { wholesaler to improving quality. }\end{array}$ \\
\hline
\end{tabular}

Sumber/ Source: diolah dari data primer, Mei 2007 / Primary Data (Processed), May 2007.

\section{Usaha Pendukung Proses Produksi Rumput Laut}

Usaha pendukung proses produksi ini merupakan simpul penting dan kondisi unit usaha pendukung ini belum berkembang seperti yang diharapkan. Unit usaha pendukung itu antara lain:

\section{a. Unit usaha pembibitan rumput laut.}

Investasi usaha penyedia bibit rumput laut belum berkembang secara komersial. Pada desa Padike Kecamatan Talango, terdapat beberapa pembudidaya rumput laut yang membeli bibit dari pembudidaya bibit rumput laut, namun penjual bibit ternyata merupakan petani pembudidaya rumput laut. Pembelian bibit rumput laut dari petani lain terjadi karena pembudidaya tersebut gagal panen atau kualitas rumput laut yang dihasilkan kurang baik. Secara umum pembudidaya rumput laut di lokasi penelitian menggunakan bibit rumput laut dari hasil panen sendiri. Penggunaan bibit dari hasil panen tersebut tidak menunjukkan penurunkan produksi, karena produksi rumput laut tersebut ditentukan oleh kesuburan perairan. Jenis rumput laut yang diusahakan petani adalah Euchema cottonii dan Euchema spinosum. Kontribusi jenis yang pertama terhadap produksi sekitar 90 - 95 persen. Hal ini disebabkan karena harga E. cottonii (Rp 5.300 per kg kering tawar) jauh lebih baik dari harga E. spinosum (Rp 2.000 per kg kering tawar).

Perkiraan kebutuhan bibit rumput laut pada lokasi penelitian dapat dipelajari dari tampilan Tabel 2. Kebutuhan bibit rumput laut per tahun diperkirakan sekitar 53 ton basah.

Tabel 2. Luas Areal, Produksi, Produktivitas dan kebutuhan bibit rumput laut pada tahun 2006 di Kabupaten Sumenep

Table 2. Area, Production, Productivity and Seaweed Seed Needs in Sumenep Sub Province, 2006

\begin{tabular}{lcccc}
\hline $\begin{array}{c}\text { Kecamatan/ } \\
\text { District }\end{array}$ & $\begin{array}{c}\text { Luas Areal / } \\
\text { Area (Ha) }\end{array}$ & $\begin{array}{c}\text { Kebutuhan bibit / } \\
\text { Seed Needs } \\
\text { (Ton) }\end{array}$ & $\begin{array}{c}\text { Produksi Basah/ } \\
\text { Wet Production } \\
\text { (Ton) }\end{array}$ & $\begin{array}{c}\text { Produktivitas/ } \\
\text { Productivity } \\
\text { (Ton / Ha) }\end{array}$ \\
\hline Gili Genteng & 12.927 & 4.169 & 23.825 & 1,8 \\
Saronggi & 37.107 & 24.725 & 141.285 & 3,8 \\
Bluto & 32.180 & 8.439 & 48.223 & 1,5 \\
Dungkek & 11.970 & 2.344 & 13.395 & 1,1 \\
Talango & 17.167 & 4.489 & 25.650 & 1,5 \\
Gapura & 8.492 & 2.811 & 16.063 & 1,9 \\
Arjasa & 6.728 & 1.934 & 11.053 & 1,6 \\
Masalembu & 2.809 & 2.607 & 14.895 & 5,3 \\
Ra'as & 3.307 & 368 & 2.100 & 0,6 \\
Sapeken & 8.637 & 942 & 5.381 & 0,6 \\
Total & $\mathbf{1 4 1 . 3 2 4}$ & $\mathbf{5 2 . 8 2 7}$ & $\mathbf{3 0 1 . 8 7 0}$ & $\mathbf{2 , 1}$ \\
\hline
\end{tabular}

Sumber: diolah dari data sekunder (Dinas Kelautan dan Perikanan Sumenep 2007)

Source : Processed Secondary Data, (Marine and Fisheries Agency of Sumenep 2007) 
Investasi untuk mendorong tumbuhnya usaha pembibitan rumput laut sangat sulit karena harga bibit jenis $E$. cottonii pada tingkat petani berkisar antara Rp 500 Rp. 1.000 per kg, sementara harga $E$. cottoni kering (tawar) sekitar Rp. 5.300 per kg.

\section{b. Unit usaha penyedia sarana produksi.}

Sarana produksi utama yang diperlukan oleh usaha budidaya rumput laut terdiri dari bambu dan tali (dikenal sebagai tali "ris"). Bambu digunakan untuk membentuk rakit sebagai tempat mengikat tali yang telah terdapat bibit rumput laut. Ukuran rakit untuk budidaya rumput laut ini bervariasi antara: $(6 \mathrm{x}$ 9) $\mathrm{m}^{2}$ dan $(7 \times 12) \mathrm{m}^{2}$. Harga bambu per batang berkisar antara Rp. 3.000 - Rp. 15.000. Bambu untuk rakit tempat budidaya rumput laut ini tahan antara 3 sampai 4 kali panen. Sementara tali yang digunakan untuk mengikat bibit rumput laut yang dibudidayakan tahan sekitar 6 kali panen.

Unit usaha penyedia sarana produksi tersebut sangat jarang ditemui pada sentra produksi rumput laut. Hal ini disebabkan karena bambu dapat diperoleh dari desa-desa sekitar (kecuali pada lokasi di daerah kepulauan yang harus mendatangkan bambu dari pulau Madura), sedangkan tali ris dapat diperoleh pada toko material di ibu kota Kecamatan atau kota Sumenep.

\section{Usaha Produksi Rumput laut}

\section{a. Unit Usaha Penghasil produk primer.}

Usaha ini merupakan usaha rumah tangga dan peran perempuan sangat dominan. Peran tersebut terlihat dalam keputusan untuk menanam, memanen, mengolah dan menjual hasil panen. Pada seluruh desa yag dikunjungi, pembudidaya rumput laut telah bergabung dalam kelompok petani budidaya rumput laut. Keanggotaan kelompok sangat longgar karena budaya merantau.

Pemilikan usaha budidaya rumput laut rata-rata 4 sampai 10 unit rakit per rumah tangga. Panen dilakukan petani pada umur 30 hari 40 hari setelah tanam. Usaha ini merupakan usaha kecil yang belum pernah mendapatkan bantuan modal. Biaya produksi rumput laut per siklus produksi dapat diperhatikan pada Tabel 3. Pada budidaya rumput laut biaya yang diperlukan untuk mebuat satu unit rakit ukuran $(7 \times 12) \mathrm{m}^{2}$ sekitar Rp. 400 ribu. Biaya operasional untuk satu siklus budidaya rumput laut berkisar antara Rp. 250 ribu. Biaya operasional tersebut terdiri dari biaya pembelian bibit (walaupun umumnya pembudidaya menggunakan bibit hasil panen sendiri), upah mengikat bibit, upah pasang bibit dirakit, upah menarik rakit ke lokasi budidaya, serta upah perawatan dan panen. Oleh sebab itu, biaya produksi rumput laut per siklus produksi adalah sekitar Rp. 650 ribu.

Hal yang terpenting dari Tabel 3 adalah produksi rumput laut yang dihasilkan petani dapat dijual dalam bentuk segar, kering tanpa garam atau kering bergaram. Hasil pengamatan dilapangan menunjukkan tidak ada petani menjual rumput laut basah kepada pedagang karena harga rumput laut basah sangat rendah E. Cottonii sekitar Rp 800 per kg dan E. Spinosum sekitar Rp. 200 per kg. Rumput laut hasil panen petani umumnya dijual dalam bentuk olahan kering tanpa garam atau kering bergaram, penjualan umumnya dilakukan setelah dikeringkan selama 2 - 3 hari.

Penjualan rumput laut dalam bentuk kering bergaram masih banyak ditemui pada lokasi penelitian. Penjualan dalam bentuk kering bergaram ini walaupun harga per satuannya relatif murah namun nilai jualnya akan lebih baik dari nilai jual rumput laut kering tanpa garam (Tabel 3). Dari sisi pembudidaya, penjualan rumput laut kering bergaram atau tanpa garam tersebut tergantung permintaan pedagang dan persyaratan. Pembeli rumput laut kering bergaram tersebut umumnya tidak memberi persyaratan yang ketat (seperti kadar air, kadar kotoran) terhadap produk yang dibelinya. Disamping itu, pada lokasi penelitian masih ada rumput laut yang dijemur diatas tanah, tujuannya diperkirakan untuk menambah berat rumput laut. 
Tabel 3. Biaya Produksi dan Pendapatan dari Budidaya Rumput Laut Jenis E. Cottoni Ukuran Rakit $(7 \times 12) \mathrm{m}^{2}$ per Siklus Produksi di Kabupaten Sumenep. 2007

Table 3. Production Cost and Revenue from Seaweed Culture E. Cottonii Type Raft Size (7x 12) $m^{2}$ per Production Cycle in Sumenep District, 2007

\begin{tabular}{|c|c|c|c|c|}
\hline Jenis Biaya / Cost Type & $\begin{array}{c}\text { Satuan / } \\
\text { Unit }\end{array}$ & $\begin{array}{c}\text { Harga per } \\
\text { Satuan / Price } \\
\text { per Unit }\end{array}$ & $\begin{array}{l}\text { Jumlah / } \\
\text { Amount }\end{array}$ & $\begin{array}{l}\text { Nilai / Value } \\
\text { (Rp) }\end{array}$ \\
\hline \multicolumn{5}{|l|}{ Biaya Tetap / Fixed Cost } \\
\hline Bambu / Bamboo & Batang/log & 5.000 & 7 & 35.000 \\
\hline Tali / Rope & $\mathrm{kg}$ & 25.000 & 7 & 175.000 \\
\hline Upah ikat bambu / Bamboo Rope Fee & unit & 50.000 & 1 & 50.000 \\
\hline Upah susun tali / rope stack fee & Ikat/rope & 200 & 100 & 20.000 \\
\hline Jaring penjemur / Dried Net & $\mathrm{m}$ & 4.500 & 30 & 135.000 \\
\hline \multicolumn{5}{|l|}{$\begin{array}{c}\text { Biaya Operasional / Operational } \\
\text { Cost }\end{array}$} \\
\hline Bibit rumput laut / Seaweed Seed & $\mathrm{kg}$ & 1.000 & 50 & 50.000 \\
\hline $\begin{array}{l}\text { Upah ikat bibit / Seaweed Rope Seed } \\
\text { Upah pasang dirakit / Seed Tide on }\end{array}$ & Tali /rope & 200 & 100 & 20.000 \\
\hline $\begin{array}{l}\text { Raft Fee } \\
\text { Ongkos menarik rakit/ Cost of Raft }\end{array}$ & Rakit/raft & 30.000 & 1 & 30.000 \\
\hline Pull & Rakit/raft & 30.000 & 1 & 50.000 \\
\hline Upah perawatan / Maintaining Cost & Hari/day & 3.000 & 15 & 45.000 \\
\hline Upah panen / Harvesting Cost & $\mathrm{x}$ & 50.000 & 1 & 50.000 \\
\hline \multicolumn{5}{|l|}{ Produksi / Production } \\
\hline $\begin{array}{l}\text { Basah / Wet } \\
\text { Kering tanpa garam / Dried without }\end{array}$ & $\mathrm{kg}$ & 800 & 500 & 400.000 \\
\hline salt & $\mathrm{kg}$ & 5.500 & 150 & 825.000 \\
\hline Kering bergaram / Dried Salted & $\mathrm{kg}$ & 4.600 & 200 & 920.000 \\
\hline
\end{tabular}

Sumber: diolah dari data primer, Mei 2007.

Source : Primary Data (Processed), May 2007

\section{b. Unit usaha pengolah produk primer menjadi bahan setengah jadi}

Di Kabupaten Sumenep terdapat tiga jenis Industri yang dapat mengolah produk primer menjadi produk setengah jadi. Produk ini selanjutnya dapat digunakan oleh industri lain sebagai bahan baku untuk proses produksi lanjutan. Produk ini dikenal sebagai semi refines carragenan.

\section{Industri yang menghasilkan Chip}

Industri ini memanfaatkan jasa pedagang pengumpul tingkat kecamatan untuk mendapat bahan baku rumput laut kering tanpa garam. Produksi chip dimulai pada tahun 2002, industri ini mampu memproduksi chip per hari antara 10 ton sampai 15 ton. Chip ini di ekspor ke China dan Malaysia. Industri ini mampu menyerap 300 orang tenaga kerja per hari. Namun saat ini produksi chip dihentikan karena ada tekanan dari luar tentang limbah dari pembuatan chip.

Saat ini perusahaan yang berlokasi di Desa Kandangan Kecamatan Bluto itu, hanya mengekspor rumput laut kering ke Malaysia, dengan serapan tenaga kerja antara $10-12$ orang. Perusahaan tersebut memperoleh bahan baku rumput laut kering untuk ekspor 
antara lain dari Sumenep, dan Nusa Tenggara Timur. Pasokan rumput laut dari luar Sumenep diperlukan karena suplai rumput laut kering tanpa garam dari Sumenep sangat terbatas. Terbatasnya suplai ini disebabkan oleh banyak pengusaha, juga mencari rumput laut kering di wilayah Kabupaten Sumenep. Perusahaan ini dalam satu bulan dapat mengirim rumput laut kering ke Malaysia sekitar 2 kontainer.

\section{Industri yang menghasilkan Chip dan Powder}

Unit pengolahan industri ini terdapat di Desa Lobuk Kecamatan Bluto, industri ini merupakan unit usaha dari PT. Madura Prima Interna. Kapasitas terpasang dari industri ini adalah 10 container per bulan, sementara kapasitas minimal untuk berproduksi adalah 2 container per bulan. Industri ini menghasilkan chip dan powder dan menyerap tenaga kerja sekitar 200 - 250 orang. Bahan baku rumput laut diperoleh dari Sumenep, Bau Bau dan Palopo. Harga bahan baku yang dibeli tergantung pada kadar air (35 - 37 persen), dan kadar kotoran sekitar 1 persen. Perusahaan ini juga membeli rumput laut kering bergaram, dan akan diolah dengan perlakuan/treatment tertentu untuk menghilangkan garam. Perusahaan ini mempunyai stok bahan baku rumput laut 500 ton per bulan.

Produk yang dihasilkan adalah 10 persen technical grade dan 90 persen food grade. Produk hasil olahan di ekspor ke China dan Eropa. Pasar ekspor menentukan kualitas produk yang sangat ketat, kualitas produk yang harus dipenuhi adalah ukuran butir / particle size 200 mesh, warna putih, kekuatan gel / gel strength 500 -700 dan tidak boleh ada jamur dan bakteri.

\section{Industri yang menghasilkan Rumput Laut Siap Saji}

Industri ini merupakan industri rumah tangga. Produk yang dihasilkan sangat beragam seperti rumput laut siap olah, jelly, dodol, manisan dan nata de coco. Volume produksi sangat terbatas dan tergantung pada permintaan. Industri ini belum berkembang, disamping karena bahan penolong untuk membuat produk tersebut tidak terdapat di Sumenep dan harus dibeli dalam jumlah besar di Surabaya, juga karena promosi dari produk tersebut di daerah tidak ada. Produk ini hanya dijual terbatas di lingkungan tertentu atau di desa terutama jika terdapat acara acara khusus. Produk tersebut belum bisa menembus pasar swalayan karena belum ada sertifikat keamanan pangan dari Departemen Kesehatan dan izin dari perindustrian. Kemasan produk belum memenuhi standar keamanan pangan.

\section{Usaha Jasa Distribusi Barang}

Pada sentra produksi rumput laut di Sumenep unit usaha ini dapat di katagorikan sebagai unit usaha perdagangan dan unit usaha transportasi barang.

\section{a). Unit usaha perdagangan rumput laut}

Pedagang besar paling paling berperan dalam usaha ini. Pedagang besar tersebut dapat merangakap sebagai pengolah. Pedagang besar umumnya berlokasi di ibukota kecamatan dan wilayah usahanya dapat terdiri dari beberapa kecamatan. Satu pedagang besar mempunyai 10 sampai 20 orang pedagang pengumpul yang selalu memasok rumput laut kering setiap minggu. Disamping itu, pedagang besar tersebut juga mempunyai pedagang pengumpul di daerah sentra produksi lain di Sulawesi dan NTT (biasanya mereka berhubungan saudara). Hubungan antara pedagang besar dengan pedagang pengumpul diikat dengan pinjaman modal, sehigga pedagang pengumpul tersebut harus menjual rumput laut yang diperolehnya kepada pedagang besar.

Jumlah pedagang besar di Kabupaten Sumenep diperkirakan sekitar 6 orang dengan skala usaha yang berbeda, sedangkan jumlah pedagang pengumpul sekitar 50 orang. Dalam pembelian barang informasi harga 
Tabel 4. Sebaran Pedagang Rumput Laut di Kabupaten Sumenep, 2007.

Table 4. Seaweed Merchant Dispertion in Sumenep Sub Province, 2007

\begin{tabular}{lcc}
\hline \multirow{2}{*}{$\begin{array}{c}\text { Lokasi Kecamatan/District } \\
\text { Location }\end{array}$} & \begin{tabular}{c} 
Jumlah Pedagang (Orang) \\
\cline { 2 - 3 } Pedagang Besar / \\
Wholesaler
\end{tabular} & $\begin{array}{c}\text { Pengumpul / } \\
\text { Collector }\end{array}$ \\
\hline Bluto & 5 & 10 \\
Saronggi & - & 7 \\
Giligenting & - & 3 \\
Talango & 1 & 10 \\
Gapura & - & 6 \\
Dungkek & - & 8 \\
Ra'as & - & 5 \\
Sapeken & - & 12 \\
\hline
\end{tabular}

Sumber: Data Primer, Mei, 2007.

Source : Primary Data (Processed), May 2007

yang dibeli oleh pedagang pengumpul diperoleh dari pedagang besar (sesuai dengan persyaratan kadar air, kadar kotoran dan kadar garam). Oleh pedagang tersebut informasi seperti ini tidak pernah disampaikan kepada pembudidaya rumput laut, asimetris informasi ini terjadi disemua desa yang dikunjungi. Sebaran pedagang rumput laut di Kabupaten Sumenep dapat diperhatikan pada Tabel 4.

Untuk mengirim barang ke Surabaya, satu pedagang besar dalam sebulan dapat mengirim 60 ton rumput laut kering bergaram dalam 6 kali kiriman. Besar modal untuk satu kali pengadaan rumput laut sampai pengiriman ke Surabaya sekitar 10 ton adalah Rp. 40 juta. Pedagang besar tersebut harus mempunyai modal yang kuat karena pembayaran yang dilakukan oleh pembeli dengan sistim konsinyasi dan akan dibayar 1 bulan kemudian.

\section{b). Unit Usaha Transportasi Barang}

Terkait dengan distribusi barang ke Surabaya, umumnya pedagang besar menggunakan jasa angkutan barang. Di Sumenep terdapat 2 perusahaan jasa transportasi barang yaitu PT. Wijaya dan PT. Murni Jaya. Perusahaan pengangkutan barang antar pulau Madura ini tergabung dalam satu sindikasi organisasi transportasi yang disebut Semut Merah, implikasinya jika ada perusahaan transportasi barang lain yang mengangkut barang dari dan ke pulau Madura harus memperoleh izin dengan membayar sejumlah tarif tertentu kepada organisasi ini.

Biaya pengiriman rumput laut ke Surabaya per truk per trip sekitar Rp. 750 ribu sampai satu juta rupiah. Biaya tersebut sudah termasuk biaya bongkar muat barang. Biasanya antara pengusaha jasa angkutan dengan pedagang besar yang memanfaatkan jasa layanan angkutan barang terjadi hubungan yang saling ketergantungan, artinya jika pedagang besar tersebut belum mempunyai biaya maka biaya tersebut untuk sementara ditalangi oleh pengusaha angkutan. Biaya tersebut akan dibayar jika pedagang besar telah menerima pembayaran dari pembeli rumput laut. Hal ini dapat dilakukan oleh pengusaha transportasi karena jumlah pengusaha trasportasi yang terbatas dan permintaan terhadap jasa transportasi cukup tinggi.

\section{Usaha Jasa Pelayanan Lainnya}

\section{a). Unit usaha Perbankan}

Jasa layanan perbankan umumnya dimanfaatkan oleh pedagang besar dalam melakukan transaksi hasil penjualan atau 
pembelian. Sementara para pembudidaya dan pedagang pengumpul jarang memanfaatkan jasa pelayanan perbankan. Saat ini terdapat beberapa bank yang beroperasi di Sumenep, baik bank milik pemerintah dan swasta, semua bank ini berlokasi di pusat kota. Sementara di pasar desa Talango terdapat satu bank desa.

Secara umum belum ada dana kredit dari perbankan yang disalurkan pada usaha budidaya rumput laut, karena pembudidaya rumput laut tidak mempunyai agunan untuk memperoleh kredit (Iskandar, 2006). Kredit yang ada merupakan kredit program yang dananya berasal dari anggaran pusat Departemen Kelautan dan Perikanan, yang disalurkan melalui Bank BRI. Kredit program ini dimanfaatkan oleh anggota kelompok koperasi Usaha Simpan Pinjam Anika Usaha di Kecamatan Saronggi. Kredit tersebut merupakan program Pemberdayaan Ekonomi Masyarakat Pesisir. Kredit program ini merupakan dana bergulir, dan menurut hasil wawancara kredit yang disalurkan tersebut merupakan dana tahun anggaran 2006.

\section{b). Unit Pelayanan Publik}

Unit pelayanan publik ini merupakan instansi pemerintah yang seyogyanya harus mendukung program pembangunan ekonomi yang terdapat disentra pengembangan rumput laut. Pengamatan lapangan menunjukkan instansi pemerintah pada wilayah tersebut belum memberikan pelayanan maksimum terhadap upaya mendorong ekonomi masyarakat setempat. Padahal, usaha industri rumput laut tersebut saat ini merupakan salah satu pengerak ekonomi penting dari ekonomi Sumenep.

Pengembangan ekonomi dengan basis usaha industri rumput laut seakan hanya bagian dari kegiatan sektoral. Sementara dinas teknis yang lain belum memberikan kontribusi yang signifikan terhadap pengembangan rumput laut. Hal ini terlihat dari kurangnya partisipasi Dinas Teknis di wilayah itu, dalam membantu unit usaha kecil untuk memperoleh izin keamanan pangan Departemen Kesehatan, dan tidak ada advokasi dari dinas teknis terhadap limbah industri rumput laut, dan tidak adanya penyuluhan tentang pasca panen rumput laut pada pembudidaya. Akibatnya unit usaha tersebut tidak dapat berkembang dengan baik dan daya saing produk rumput laut asal Sumenep menjadi rendah karena kualitas yang tidak sesuai dengan persayaratan produk kualitas baik.

\section{c). Unit Penelitian dan Pengembangan}

Catatan sejarah menunjukkan pengembangan rumput laut di Kabupaten Sumenep didorong oleh percobaan budidaya rumput laut oleh Badan Pengkajian dan Penerapan Teknologi (BPPT) pada tahun 1980. Percobaan tersebut ditindaklanjuti oleh Bappeda Provinsi Jawa Timur pada tahun 19811982 untuk mengembangkan budidaya rumput laut jenis $E$. cottonii dan E. spinosum di Kecamatan Giligenting dan Kecamatan Sepeken. Keberhasilan ini mendorong tumbuhnya usaha budidaya rumput laut di Sumenep, sehingga pada tahun 1989 PT. Sumba Subur menanamkan investasinya dalam usaha rumput laut di Sumenep. Pada tahun 1991, sekitar 6 investor menanamkan modal dalam perdagangan rumput laut di Sumenep.

Pada tahun 1993 - 1996 usaha budidaya rumput laut di Kabupaten Sumenep mengalami kemunduran, karena harga yang diterima pembudidaya sangat rendah. Tekanan harga rumput laut tersebut disebabkan oleh pesaingan yang tidak sehat antara investor yang menanamkan modalnya di Sumenep dalam memperoleh bahan baku rumput laut. Akibatnya selama periode tersebut banyak pembudidaya rumput laut tidak membudidayakan rumput laut, karena harga rumput laut pada tingkat pembudidaya tidak menarik lagi. Krisis moneter tahun 1997 mendorong usaha budidaya rumput laut ini berkembang lagi, karena harga rumput laut 
mengkuti nilai tukar dolar amerika.

Saat ini usaha budidaya tersebut masih terus berkembang, namun kualitas pasca panen rumput laut pada tingkat pembudidaya sangat bervariasi. Untuk memperbaiki kualitas lembaga penelitian telah melakukan berbagai terobosan, tetapi dalam skala yang luas peran penyuluh dan pedagang besar dalam meningkatkan kualitas rumput laut lebih penting lagi.

\section{Kendala Unit Usaha dilokasi Penelitian}

Pengembangan industri rumput laut di Kabupaten Sumenep dihadapkan pada berbagai kendala baik yang berasal dari unit usaha tersebut (spesifik) atau dari luar unit usaha tersebut (umum). Kendala dari unit usaha tersebut umumnya sangat bervariasi mulai dari technical skill pengelolaan unit usaha serta pemahaman terhadap permasalahan pasca panen. Permasalahan yang dihadapi oleh setiap jenis usaha tersebut dapat di perhatikan pada Tabel 5.

\section{Tabel5. Kendala dalam Pengembangan Usaha Industri Rumput Laut Di Kabupaten Sumenep, 2007}

Table 5. Constraint of Seaweed Industry Development in Sumenep Sub Province, 2007

\begin{tabular}{|c|c|}
\hline \multirow{2}{*}{$\begin{array}{c}\text { Jenis } \\
\text { Usaha/Business Type }\end{array}$} & Kendala \\
\hline & Umum/General \\
\hline $\begin{array}{l}\text { Usaha pembenihan } \\
\text { rumput laut/Seaweed } \\
\text { seeding business }\end{array}$ & $\begin{array}{l}\text { Usaha ini tidak dapat dijadikan } \\
\text { sebagai usaha yang mandiri } \\
\text { karena harga bibit rumput laut pada } \\
\text { lokasi berkisar antara Rp. } 500- \\
\text { Rp. } 1.000 \text { per kg. Sementara harga } \\
\text { rumput laut setelah dikeringkan } \\
\text { mencapai Rp. } 4.600 \text { per kg - } 5.500 \\
\text { per kg. Disparitas harga ini } \\
\text { mendorong rumput laut hanya } \\
\text { diusahakan sebagai bahan baku } \\
\text { industri./ This business cannot be } \\
\text { made as self-supporting business } \\
\text { because seaweed seed price at } \\
\text { location range from Rp. } 500 \text { - Rp. } \\
1.000 \text { per kg. While dried seaweed } \\
\text { to reach Rp. } 4.600 \text { per kg - } 5.500 \\
\text { per kg. this Price Disparitas push } \\
\text { seaweed only laboured as } \\
\text { industrial raw material. }\end{array}$ \\
\hline
\end{tabular}

Sarana

Produksi/Production Aquipment
Sarana produksi seperti bambu untuk rakit akan sangat langka jika terjadi ekstensifikasi budidaya rumput laut. Pada wilayah kepulauan harga bambu saat ini mencapai Rp. 15 ribu per batang, karena terjadi kelangkaan bambu./Production equipment such as bamboo for raft will be rare if seaweed cultured extensification happen. In island region, bamboo price is Rp. 15 thousand per piece because rare of bamboo. 


\begin{tabular}{|c|c|c|}
\hline \multirow{2}{*}{$\begin{array}{c}\text { Jenis } \\
\text { Usaha/Business Type }\end{array}$} & \multicolumn{2}{|c|}{ Kendala /Constraint } \\
\hline & Umum/General & Spesifik/Specific \\
\hline $\begin{array}{l}\text { Pembudidaya Rumput } \\
\text { Laut/Seaweed cultured }\end{array}$ & $\begin{array}{l}\text { Ekspansi budidaya rumput laut } \\
\text { akan memerlukan penataan ruang } \\
\text { untuk menghindari konflik di } \\
\text { perairan / Seaweed expansion will } \\
\text { need settlement of space to avoid } \\
\text { conflict in territorial water. }\end{array}$ & $\begin{array}{l}\text { 1. Diperlukan tenaga pendampingan } \\
\text { untuk membina manajemen } \\
\text { budidaya, dan pasca panen pada } \\
\text { tingkat pembudidaya./ Instructor } \\
\text { is needed to constructing } \\
\text { aquaculture management and } \\
\text { post harvest } \\
\text { 2. Modal pengembangan usaha } \\
\text { tidak ada dan sulit diperoleh dari } \\
\text { lembaga perbankan./No capital to } \\
\text { business development and } \\
\text { difficult to get from banking } \\
\text { institution }\end{array}$ \\
\hline $\begin{array}{l}\text { Industri } \\
\text { Pengolahan/ } \\
\text { Processing industry }\end{array}$ & $\begin{array}{l}\text { Kapasitas terpasang industri } \\
\text { pengolahan yang ada lebih besar } \\
\text { dari kapasitas suplai bahan baku / } \\
\text { Existing industry capacity available } \\
\text { is bigger than raw material supply } \\
\text { capacity }\end{array}$ & $\begin{array}{l}\text { Perlu advokasi penanganan masalah } \\
\text { limbah hasil olahan rumput laut./ } \\
\text { Need advocacy to handling of waste } \\
\text { problem seaweed processing }\end{array}$ \\
\hline Pedagang/Merchant & $\begin{array}{l}\text { Pembeli membayar dengan sistim } \\
\text { konsinyasi./Buyers pay by } \\
\text { konsinyasi system }\end{array}$ & $\begin{array}{l}\text { Keterbatasan modal, karena } \\
\text { pedagang harus membayar tunai } \\
\text { pada pembudidaya./ Capital } \\
\text { limitation, because merchant has to } \\
\text { pay cash to fish farmer }\end{array}$ \\
\hline $\begin{array}{l}\text { Usaha Pendukung } \\
\text { lainnya/Others } \\
\text { Supporting Business } \\
\text { Unit }\end{array}$ & $\begin{array}{l}\text { Usaha pendukung lainnya masih } \\
\text { belum fokus dalam } \\
\text { mengembangkan industri rumput } \\
\text { laut./Others supporting business } \\
\text { unit not focus on developing } \\
\text { seaweed industry }\end{array}$ & $\begin{array}{l}\text { Program prioritas dari unit pendukung } \\
\text { saling berbeda dan tidak spesifik } \\
\text { pada pengembangan rumput } \\
\text { laut./Priority program from supporting } \\
\text { unit is different each other and not } \\
\text { specific for seaweed developing }\end{array}$ \\
\hline
\end{tabular}

Sumber/ Source: Data Primer, Mei, 2007/Primary Data (Processed), May 2007

Berdasarkan Tabel 5, kedala umum dari masing-masing jenis usaha harus diselesaikan dengan memperbaiki sistem hubungan antara jenis usaha yang terdapat di Kabupaten Sumenep. Perbaikan sistem ini memerlukan suatu program yang terpadu dengan mengikutsertakan seluruh unit usaha untuk pengembangan industri tersebut. Sistem tersebut harus dapat membangun core industri yang menjadi sentral dari pengembangan klaster rumput laut di Sumenep. Sementara itu kendala spesifik menyangkut beberapa dukungan yang diperlukan oleh jenis usaha tersebut seperti advokasi dan bantuan dalam memperbaiki kinerjanya untuk ekspansi usaha.

\section{Hubungan antar Unit Usaha di Lokasi Penelitian}

Hubungan unit usaha industri rumput laut dapat dilihat dalam bentuk hubungan horizontal dan hubungan vertikal. Hubungan horizontal menunjukkan relasi kerja sama dari jenis usaha yang sama karena merebut segmen pasar yang sama, skill tenaga kerja yang seragam dan sumberdaya yang sama. Sementara hubungan vertikal menunjukkan relasi kerja sama antara jenis usaha yang berbeda dalam memenuhi permintaan pasar.

Relasi horizontal sesama unit usaha: pendukung proses produksi, usaha produksi, dan distribusi barang menunjukkan hubungan yang sinergis, hal ini berarti tidak ada 
persaingan yang negatif dari setiap unit jenis usaha. Saat ini pada setiap kelompok jenis usaha yang terakhir itu, dapat dikatakan terbangun suatu kerja sama yang baik untuk mengembangkan usaha terutama dalam hal pemanfaatan tenaga kerja, dan informasi tentang teknologi produksi. Sementara itu, konflik relasi horizontal terjadi pada usaha perdagangan dan industri pegolahan produk primer menjadi intermediate product. Konflik ini muncul karena persaingan dalam memperoleh bahan baku rumput laut, oleh sebab itu pedagang besar dan industri pengolahan tersebut saling bersaing untuk merebut bahan baku pada tingkat pembudidaya. Persaingan ini mendorong tidak adanya insentif harga pada tingkat pembudidaya rumput laut sehingga penanganan pasca panen terhadap rumput laut sangat buruk. Persaingan tersebut pada sisi lain menyebabkan industri pengolahan rumput laut yang ada di Sumenep sangat tertutup dalam hal mutu bahan baku yang diperlukan dan kualitas produk yang dihasilkan.

Pada sisi lain hubungan vertikal antar komponen usaha industri rumput laut cenderung mendorong terjadi asimetris informasi terutama antara pembudidaya rumput laut dengan pedagang. Asimetris informasi ini terutama terjadi dalam hal persyaratan kualitas rumput laut yang harus dihasilkan petani, dan harga rumput laut pada tingkat petani. Asimetris informasi tentang kualitas rumput laut yang dhasilkan petani tersebut diketahui, karena pedagang yang membeli rumput laut tersebut tidak pernah memberi informasi akurat tentang kadar air yang diperlukannya serta kadar kotoran yang terdapat pada rumput laut tersebut. Kadar air diukur secara manual dengan menggunakan genggaman tangan, sedangkan kadar kotoran hanya berdasarkan visual, kedua ukuran tersebut sangat normatif.

Ukuran normatif tersebut dapat berbeda menurut waktu, tempat dan pembeli. Ukuran normatif yang demikian menyebabkan petani tidak mempunyai hak tawar terhadap komoditas rumput laut yang dijualnya. Akibatnya harga rumput laut pada tingkat petani relatif rendah dan tidak seragam antara satu pembudidaya dengan pembudidaya yang lain. Asimetris informasi ini mendorong petani menangani produk hasil panen rumput lautnya tidak menurut permintaan konsumen.

\section{Perspektif Pengembangan Klaster Perikanan}

Sebagai gambaran tidak semua klaster yang terdapat di Indonesia dapat berjalan dengan sempurna. Seperti yang dikatakan oleh Nasution (2006) beberapa klaster setelah diimplemetasikan dapat beroperasi dengan baik, namun sebagian klaster terlihat tidak dapat beroperasi seperti yang diharapkan. Kegagalan berfungsinya klaster tersebut menurut Humphrey dan Schmitz (1995), karena pembentukan klaster tersebut kurang mempertimbangkan prinsip: customer oriented, collective dan cumulative.

Hasil identifikasi dilokasi penelitian komponen-komponen pembentuk klaster rumput laut di Kabupaten Sumenep dapat dikelompokkan sebagai berikut: 1). Kelompok unit usaha yang mendukung proses produksi. 2). Kelompok unit usaha proses produksi rumput laut 3). Kelompok unit usaha jasa distribusi barang. 4). Kelompok jasa pendukung.

Unit usaha pembentuk klaster tersebut dalam menjalankan usahanya harus berfungsi sinergi satu dengan lainnya dengan menempatkan diri secara proporsional pada posisi masing-masing. Fungsi itu dibangun berdasarkan hubungan kedepan (fordward lingkages), dan hubungan kebelakang (backward lingkages) dari masing masing unit usaha. Bentuk hubungan kedepan dan kebelakang dari industri ini dapat diperhatikan pada Gambar 1.

Hubungan kebelakang industri pengolahan chip tergantung pada pedagang besar rumput laut tanpa garam (rumput laut kering tawar), usaha budidaya rumput laut, 
usaha pembenihan rumput laut, dan usaha penyedia sarana produksi. Sementara keterkaitan kedepan dari industri chip rumput laut tergantung pada jasa transportasi darat, industri makanan dan minuman dalam negeri, industri non makanan, jasa transportasi ekspor serta pasar ekspor. Industri ini juga kedepan terkait juga pada peran dari jasa perbankan, penelitian dan pengembangan dan instansi pemerintah.

Selain itu hubungan kebelakang industri pengolahan chip dan powder tergantung pada pedagang besar rumput laut bergaram, usaha budidaya rumput laut, usaha pembenihan rumput laut, dan usaha penyedia sarana produksi. Sementara keterkaitan kedepan dari industri powder dan chip rumput laut tergantung pada jasa transportasi darat, industri makanan dan minuman dalam negeri, industri non makanan, jasa transportasi ekspor serta pasar ekspor. Industri ini juga kedepan terkait juga pada peran dari jasa perbankan, penelitian dan pengembangan dan instansi pemerintah.

Saat ini keterkaitan kedepan dan kebelakang dari industri itu belum tertata

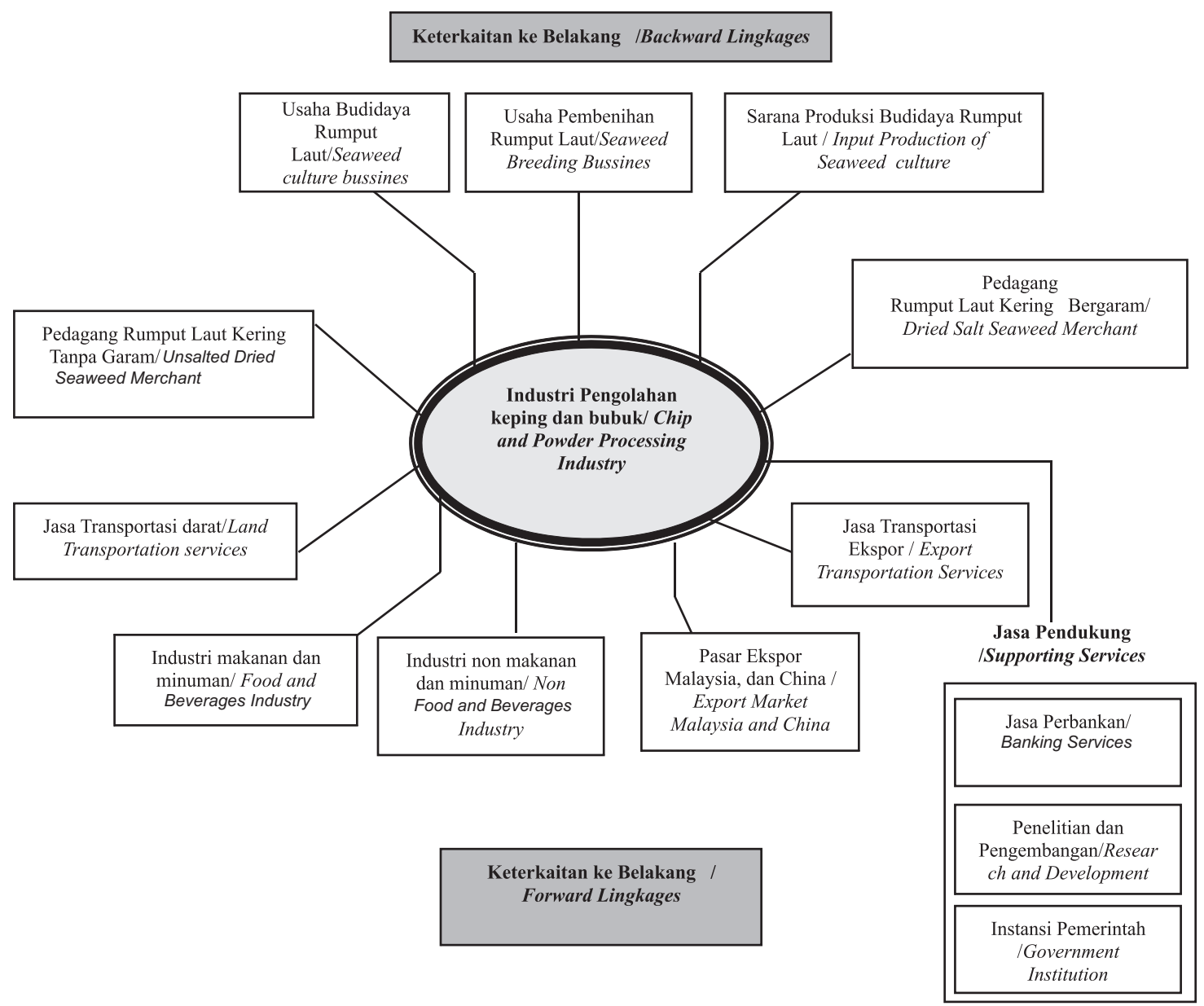

\section{Gambar 1. Keterkaitan Kedepan dan Kebelakang Klaster Rumput Laut Di Kabupaten Sumenep.}

Figure 1. Forward and Backward Lingkage of Seaweed Cluster in Sumenep Sub Province 
dengan baik, artinya hubungan kerja sama dari setiap unit usaha tersebut dibangun atas mekanisme pasar. Hubungan yang demikian akan dapat mempengaruhi kinerja unit usaha kecil dengan modal yang terbatas.

\section{KESIMPULAN DAN REKOMENDASI KEBIJAKAN}

Komponen-komponen pembentuk klaster rumput laut telah terbentuk secara alami di Sumenep. Komponen-komponen tersebut terdiri dari jenis usaha pendukung proses produksi, jenis usaha proses produksi rumput laut, jenis usaha perdagangan dan distribusi, jenis usaha jasa pendukung. Saat ini komponen-komponen tersebut belum tertata dengan baik, sehingga kinerja dari industri rumput laut di Kabupaten Sumenep belum optimal.

Terkait dengan upaya memfungsikan klaster rumput laut, maka terdapat tiga prinsip yang perlu dipertimbangkan agar klaster tersebut berfungsi secara optimal, pertama, unit usaha dalam klaster rumput laut harus berorientasi pada permintaan konsumen (consumer oriented), klaster harus bersifat kolektif, dan klaster dapat memperbaiki daya saing secara kumulatif.

Disamping itu untuk menumbuhkan klaster, diperlukan tiga tahapan dalam pengembangan klaster, tahapan pertama adalah tahap persiapan yang dikenal sebagai tahap pembangunan klaster, tahap kedua adalah tahap konsolidasi disebut sebagai tahap operasi, dan tahap ketiga adalah tahap independensi beroperasinya klaster.

Pengembangan klaster rumput laut di Kabupaten Sumenep memerlukan pembenahan, karena secara vertikal terjadi asimetris informasi tentang harga bahan baku rumput laut kering dan kualitas rumput laut yang dibutuhkan pasar. Asimetris informasi tersebut terjadi karena persaingan memperoleh bahan baku rumput laut kering oleh core industri pembentuk klaster.

Dengan demikian pengembangan klaster rumput laut di Sumenep harus memperhatikan keterkaitan kebelakang dan keterkaitan kedepan dari core industri rumput laut. Terdapat dua jenis industri pengolah rumput laut yang dapat dijadikan core klaster rumput laut di Sumenep, pertama adalah industri pengolah rumput laut yang menghasilkan chip, dan kedua industri pengolah rumput laut yang menghasilkan chip dan powder. Industri yang pertama memerlukan bahan baku rumput laut kering tanpa garam, sedangkan industri yang kedua memerlukan bahan baku rumput laut kering tanpa garam atau bergaram.

\section{DAFTAR PUSTAKA}

Abdullah P. 2000. Daya Saing Daerah. BPFE. Jogyakarta.

Direktorat Pengembangan Kawasan Khusus dan Tertinggal, 2004. Kajian Strategi Pengembangan Kawasan dalam Rangka Mendukung Akselerasi Peningkatan Daya Saing Daerah. Bapenas. Jakarta.

Humprey. J and H. Schmitz, 1995. Principle for Promoting Clusters and Networks of SMEs. UNIDO.

Iskandar, T. 2006. Penyaluran Kredit Revolusi Biru di Rumput Laut. Infobanknews. Com. 2 Oktober 2006.

JICA. 2003. The Study on Strenghthening Capacity of SME Cluster in Indonesia. KRI International Corp. (unpublish report).

Kuncoro, Mudrajat, Sumarno dan S. Bambang. 2003. Indonesia's Clove Cigaret Industry, Cluster Analysis. $5^{\text {th }}$ IRCA Conference.

Nasution A.H. 2006. Pengembangan Klaster Jawa Timur, Bagaimana seharusnya?. www.its.ac.id/berita.php?nomer=2443. ITS-Surabaya.

Porter. M.E 1990. Keunggulan Bersaing, Menciptakan dan Mempertahankan Kinerja Unggul. Harvard Business Review. (Terjemahan). 